\title{
Research on Job Stress and Nurse Performance
}

\author{
Sweetina Merkusi ${ }^{1}$, Qurratul Aini ${ }^{2}$ \\ Correspondence Author: qurrotul_aini@umy.ac.id \\ ${ }^{1}$ Masters of Hospital Administration, Universitas Muhammadiyah Yogyakarta, Bantul City, Indonesia \\ 2Masters of Hospital Administration, Universitas Muhammadiyah Yogyakarta, Bantul City, Indonesia
}

\section{N D E X I N G}

Keywords:

Job Stress;

Nearly Injury

Incidence
Kata kunci:

Stress kerja,; Kejadian Nyaris Cedera

\begin{abstract}
A B S T R AC T
In 2018-2019 there was an increase in patient visits at Kumala Siwi Kudus General Hospital, recorded to reach 4253 patients and an increase in BOR reaching $85.88 \%$. This phenomenon resulted in an increased workload. Along with the increase in workload and the limited number of nurses providing services, it causes stress, which causes the nurse's condition to become unstable. In January 2019, a 2nd-year verification survey was carried out by KARS, which obtained recommendations to be followed up, especially reports of patient safety incidents. There was an increase in incidents from year to year, starting from 2016-2018. This study aims to determine the effect of work stress on the incidence of near injury and its impact on inpatient nurses' performance. This type of research is a quantitative study with a crosssectional survey in this study amounted to 68 nurses in the Inpatient Installation of Kumala Siwi Kudus Hospital. This type of research is quantitative research; it is proven that stress affects nurses' perceptions of near misses and inpatient nurses' performance.
\end{abstract}

Pada tahun 2018-2019 terjadi peningkatan kunjungan pasien di RSUD Kumala Siwi Kudus tercatat mencapai 4253 pasien dan peningkatan BOR mencapai $85,88 \%$. Fenomena ini mengakibatkan beban kerja meningkat. Seiring dengan meningkatnya beban kerja dan terbatasnya jumlah perawat yang memberikan pelayanan, menyebabkan stres yang menyebabkan kondisi perawat menjadi tidak stabil. Pada Januari 2019 telah dilakukan survey verifikasi tahun ke-2 oleh KARS, yang mendapatkan rekomendasi untuk ditindaklanjuti terutama laporan insiden keselamatan pasien. Terjadi peningkatan insiden dari tahun ke tahun mulai tahun 2016-2018. Penelitian ini bertujuan untuk mengetahui pengaruh stres kerja terhadap kejadian near injury dan dampaknya terhadap kinerja perawat rawat inap. Jenis penelitian ini adalah penelitian kuantitatif dengan survey cross sectional dalam penelitian ini berjumlah 68 perawat di Instalasi Rawat Inap RSUD Kumala Siwi Kudus. Jenis penelitian ini adalah penelitian kuantitatif; terbukti bahwa stres mempengaruhi persepsi perawat tentang kejadian nyaris celaka dan kinerja perawat rawat inap.

(C) 2020 JMMR. All rights reserved

\section{INTRODUCTION}

Data from the medical records of RSUKumala Siwi Kudus 2018 BOR reached 75.65\%. An increase in BOR reached $85.88 \%$ in 2018. The number of patient visits was recorded as 4253 patients with various cases such as Congestive Heart Failure, Hypertension, Abdominal Pain, Chronic Kidney Failure, Fever or Febris, Diarrhea, Vomiting and Nausea, Bronchopneumonia, Diabetes Mellitus, Dengue or DHF, Fractures post traffic accidents, and other cases. Kumala Siwi Kudus Hospital is a private hospital that provides services to patients as much as possible. With 116 people, the number of nurses and divided into several installations. A large number of visits will require treatment and require treatment by doctors and nurses in the hospital (HR Department RSU Kumala Siwi Kudus). 
In the last two years, Kumala Siwi Hospital has experienced a lot of patient visits to increase nurses' work activities. This phenomenon occurs because nurses have to do reasonably dense work, meaning that their workload is increasing. Along with the increase in workload and the limited number of nurses providing services, it causes stress, which causes the nurse's condition to become unstable. When the nurse is not feeling well, the nurse will check with the doctor on duty, and if the nurse's health condition needs rest, the nurse will get permission from the doctor not to come to work. It was triggered by nurses who took a lot of medication because their conditions were not healthy; Report from HRD every month. 5-10 sick letters come in so that there is a frequent shortage of nurses on duty in the inpatient room every shift. Data from HRD for employee turnover is also very high for nurses every month there are around 20 percent resigned during 2018.

Kumala Siwi Kudus Hospital has been accredited by KARS and received the 2012 version of the PARIPURNA predicate since February 2017 and has been verified for the 2nd year, 2020, re-accredited with SNARS ed 1. Hospitals in improving quality and services must refer to KARS accreditation and prioritize safety patient (patient safety) and make the culture in hospital service perfect.

Hospitals providing services to patients in the hospital must be of standard and quality, and researchers obtained data from the TKPRS (Hospital Patient Safety Team) to report unexpected incidents to increase in 2018. Reports from the TKPRS Team were 27 unexpected incidents in 3 years. The last is mainly due to errors by officers. The IKP (Patient Safety Incident) report has been followed up and reported to the director.

\section{RESEARCH METHOD}

The sample in this study amounted to 68 nurses in the Inpatient Installation of Kumala Siwi Kudus Hospital. This research is a quantitative study using a cross-sectional survey method, and this research is intended to test the hypothesis. This study looked at the effect of stress (X1) and workload (X2) on the Near Miss / KNC (Y1) incidence and Inpatient Nurse Performance (Y2). In analyzing the data, the researcher used PLS (Partial Least Square Regression). To minimize error (error), a significant level $(\alpha)$ of 0.05 was used. The unit of analysis is a nurse in the inpatient installation of Kumala Siwi Kudus Hospital.

\section{RESULT AND DISCUSSION}

Based on Figure. 1 shows that all variables in this model have a path coefficient with a positive number. The higher the path coefficient values on one independent variable on the dependent variable, the stronger the influence between the independent variables on the dependent variable. 


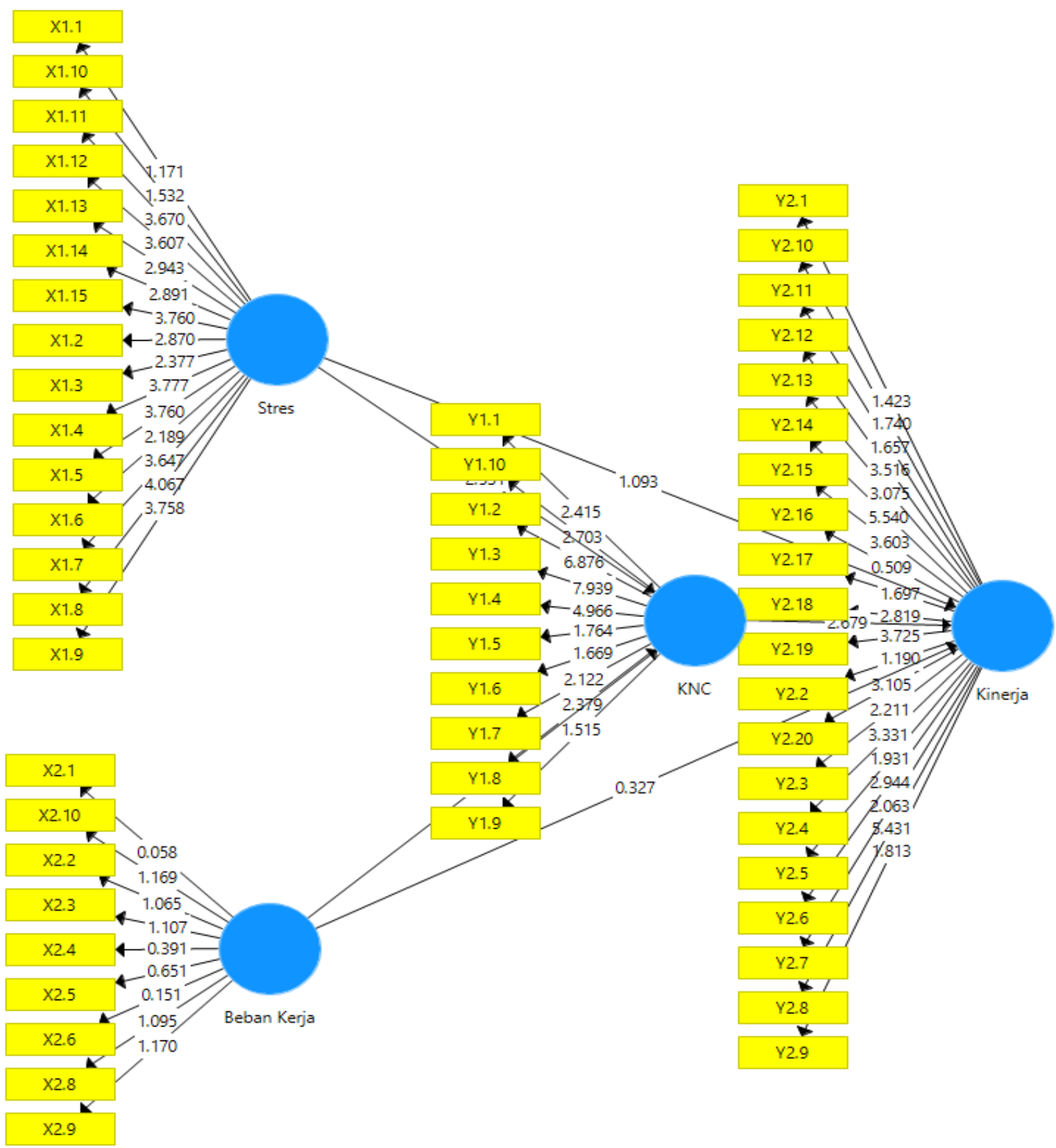

Figure. 1 The results of the path coefficient value on the variable

Based on the results of the above research it can be concluded that the sources of work stress for nurses in inpatient installations can be identified and there is an effect of work stress with the perception of near injury events and the impact of work stress on the performance of nurses in inpatient installations, and the incidence of near injury has an effect on performance. Inpatient installation nurses (Dimitra et al., 2018) (Sakano et al., 2012).

Based on this research, it is also proven that the work stress of nurses has more influence on the performance of nurses with P-Value0.035, and Perceptions of KNC / Near Miss on the performance of nurses with a P-value of 0.009 , so that job stress contributes to 
the perception of $\mathrm{KNC} / \mathrm{Near}$ Miss and its impact on performance. Based on the results of this study, the work stress of nurses based on the type of stress is Situational stress, in this case, it is associated with nurses who feel stress when they get a frightening situation that cannot be controlled in dealing with patients whose conditions are severe, causing conflict, causing errors in their work units and loss of confidence in their work to handle patients.

A natural thing if every institution or organization wants excellent performance. Therefore, every individual or employee involved in an institution or organization must have a general awareness that the return of individuals or employees greatly influences an institution's actual performance. For this reason, every individual or employee is always required to be able to carry out their duties and responsibilities to achieve organizational goals (Elder et al., 2019)(Chesak et al., 2019). A workload that is too heavy will increase the occurrence of poor communication between nurses and patients, failure of collaboration between nurses and doctors, leaving nurses, and nurses' job dissatisfaction (Syarianingsih Syam \& Kurnia Widi Hastuti, 2018). To estimate the workload of nurses on a unit, managers should collect data on the number of patients treated in the unit each day/month/year, condition or degree of dependence of patients in the unit, average days of care, type of action required of patients, frequency each nursing action performed, the average time needed to provide a nursing action (Dubois et al., 2013)(Onyebuchukwu et al., 2015)(Sabra, 2014). It is evidenced by Trisna (2007) results that the indirect activities of nurses are widely practiced in inpatient units, and the factors that affect workload are the number of patients, the number of nurses, the number of events. (Lu et al., 2019)(Hamim, 2015)(Younes et al., 2012)

A high workload can cause stress and decrease the quality of nursing care so that the behavior of caring for nurses does not apply to the health care process (Journal of Nursing Indonesia, 2012)(Simajorang et al., 2017) and is discussed by (Hamim, 2015). To deal with stress, what each individual can do differently is by thinking positively; improve one's personal life; own separate life from work; and identifying effective individual strategies. (Miyata et al., 2015) (Sarafis et al., 2016).

Stress factors and workload are factors that can influence the occurrence of Patient Safety Incidents after this referred to as Incidents are any accidental events and conditions that result in or have the potential to result in preventable injury to the patient (Ross et al., 2018) (Carlesi et al., 2017).

A hospital that can compete in the market is a hospital that can provide quality products or services. Therefore, hospitals are required to continue to make improvements, especially in service quality (Chu \& Hsu, 2011). The competency-performance modification model shows competence, organizational culture, leadership, and Commitment to increasing nurses' motivation. It also proves that motivation plays an essential role in increasing job satisfaction and nurse performance (Aini, 2018) (Carlesi et al., 2017).

Researchers made a patient safety incident reporting application that hospitals can use to cultivate the importance of patient safety in the hospital. Every employee can access and directly report without having to fear getting sanctions from patient safety incident reporting; with this application, the hope of reporting can be maximized (Ayabe et al., 2018). The incidence rate has decreased and may not exist in the future so that patients can obtain complete service at the hospital. 


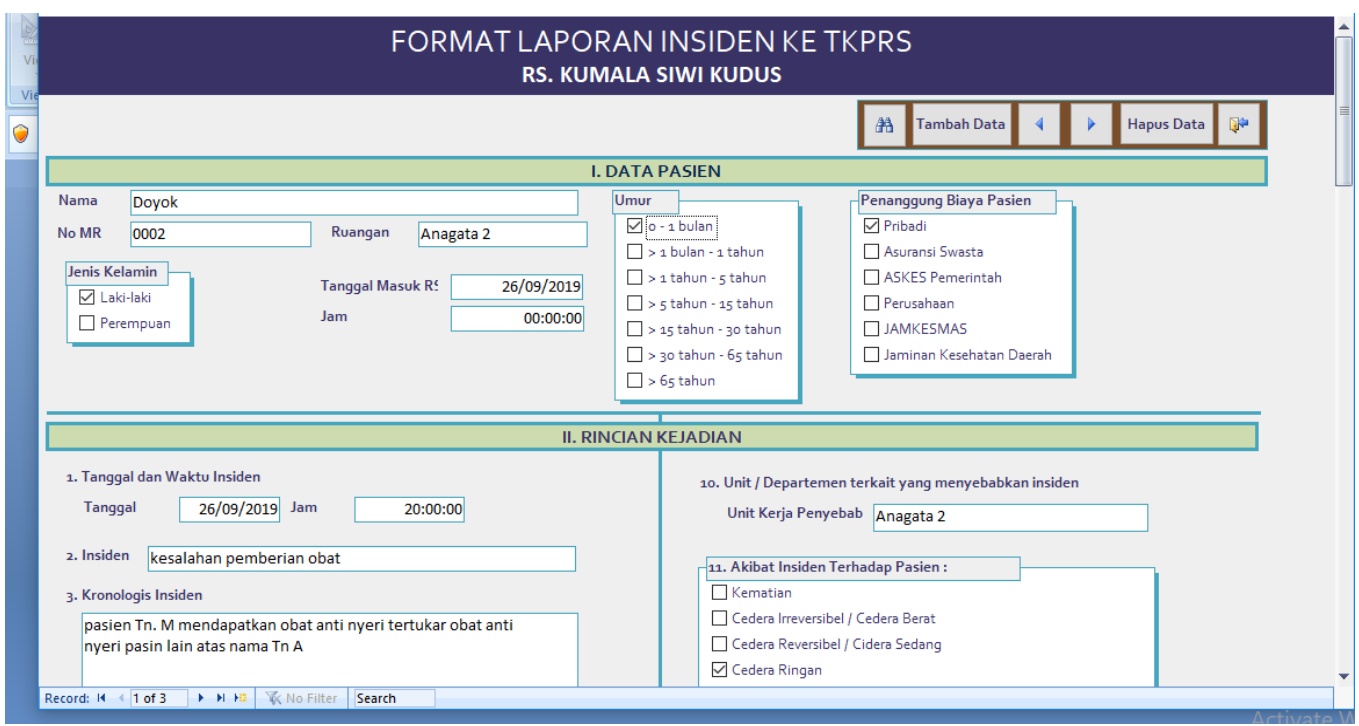

Figure.2 Application of Patient Safety Incident Reporting at Kumala Siwi Kudus Hospital

Completing in a patient safety incident report that has been done from September 2019 to November 2019 much helped the KPRS Team at the Kumala Siwi Kudus Hospital for some and made it easier for the patient safety culture to be a priority for all employees, especially nurses inpatient installation (Ross et al., 2018)(Roberts \& Grubb, 2014).

\section{CONCLUSION}

Stress affects nurses' perceptions of near-miss and the performance of inpatient nurses. Based on the results of this study, the work stress of nurses based on the type of stress is Situational stress, in this case, it is associated with nurses who feel anxiety when they get a frightening situation that cannot be controlled in dealing with patients whose conditions are severe, causing conflicts, causing errors in their work units and loss of confidence in their work in handle patients.

\section{ACKNOWLEDGMENT}

The authors would like to acknowledge a research grant from Ministry of Research, Technology and Higher Education Republic of Indonesia (Kemenristekdikti) for the funding support of the research project (Hibah Penelitian Unggulan Perguruan Tinggi 2020 Nomor: 426.f / A.3-VIII/LP3M/VI /2O20).

\section{REFERENCE}

Aini, Q. (2018). Motivation, Commitment and Leadership skill in Affecting Performance Hospital Managers. The Journal of Social Scences Research, 4(12), 707-710.

Ayabe, T., Tomita, M., Okumura, M., Shimizu, S., \& Uchida, E. (2018). Evaluation and Outcomes of Multidisciplinary-Reported Incidents Regarding Patient Safety Management at Special Functioning Hospital in Japan. Open Journal of Safety Science and Technology, 8, 107-136. https://doi.org/10.4236/ojsst.2018.84007 
Carlesi, K. C., Toffoletto, M. C., Henriquez-roldán, C., Andrea, M., \& Juan, C. (2017). Patient Safety Incidents and Nursing Workload 1. Rev. Latino-Am. Enfermagem, 25. https://doi.org/10.1590/1518-8345.1280.2841

Chesak, S. S., Cutshall, S. M., Bowe, C. L., Montanari, K. M., \& Bhagra, A. (2019). Stress Management Interventions for Nurses. Journal of Holistic Nursing, 10, 1-8. https://doi.org/10.1177/0898010119842693

Chu, C., \& Hsu, Y. (2011). Hospital Nurse Job Attitudes and Performance: The Impact of Employment Status. Journal of Nursing Research, 19(1), 53-60. https://doi.org/10.1097/JNR.0b013e31820beba9

Dimitra, C., Tsounis, A., Markopoulos, N., \& Sarafis, P. (2018). Occupational Stress Experienced by Nurses Working in a Greek Regional Hospital: A Cross-sectional Study Occupational Stress Experienced by Nurses Working in a Greek Regional Hospital: A Cross - sectional Study. Journal of Nursing and Midwifery Research, 23(6), 450-457. https://doi.org/10.4103/ijnmr.IJNMR

Dubois, C., Amour, D. D., Pomey, M., Girard, F., \& Brault, I. (2013). Conceptualizing performance of nursing care as a prerequisite for better measurement: A systematic and interpretive review. Dubois et al. BMC Nursing, 12(7).

Elder, E., Johnston, A. N. B., Wallis, M., Greenslade, J. H., \& Crilly, J. (2019). Emergency clinician perceptions of occupational stressors and coping strategies: A multi-site study. International Emergency Nursing, 45(March), 17-24. https://doi.org/10.1016/j.ienj.2019.03.006

Hamim, N. (2015). Workload and Work Stress on Caring Behavior in nurse on Nursing Services. 5(3), 148-160. https://doi.org/10.5296/ijhrs.v5i3.8236

Lu, F., Xu, Y., Yu, Y., Li, P., Wu, T., Wang, T., Xie, J., Xu, S., \& Li, M. (2019). Moderating Effect of Mindfulness on the Relationships Between Perceived Stress and Mental Health Outcomes Among Chinese Intensive Care Nurses. https://doi.org/10.3389/fpsyt.2019.00260

Miyata, A., Arai, H., \& Suga, S. (2015). Nurse Managers Stress and Coping. November, 957-964.

Onyebuchukwu, J., View, I. N., \& Emerenwa, B. C. (2015). Stress and its management. 2(12), $1-8$.

Roberts, R. K., \& Grubb, P. L. (2014). The Consequences of Nursing Stress and Need for Integrated Solutions. 62-69. https://doi.org/10.1002/rnj.97

Ross, C., Rogers, C., \& King, C. (2018). Safety culture and an invisible nursing workload. Collegian. https://doi.org/10.1016/j.colegn.2018.02.002

Sabra, A. A. (2014). Job performance among nurses working in two different health care levels, Eastern Saudi Arabia: A comparative study Research Article Job Performance Among Nurses Working In Two Different Health Care Levels , Eastern Saudi Arabia: A Comparative Study. International Journal of Medical Science and Public Health, 3(October). https://doi.org/10.5455/ijmsph.2014.240420142

Sakano, N., Suzue, T., Miyatake, N., Miyamae, Y., \& Nagatomi, T. (2012). Factors associated with psychological distress of Public Health Nurse in Kagawa prefecture, Japan: A pilot study. Open Journal of Nursing, 2(March), 23-26. 
Sarafis, P., Rousaki, E., Tsounis, A., Malliarou, M., Lahana, L., \& Bamidis, P. (2016). The impact of occupational stress on nurses ' caring behaviors and their health related quality of life. BMC Nursing, September. https://doi.org/10.1186/s12912-016-0178-y

Simajorang, A., Dalimunthe, R. F., Erna, M., \& Silaban, G. (2017). The Influence Of Job Stressor To Performance Of Nurses In Pirngadi General Hospital of Medan-Indonesia. 3(3), $12-17$.

Syarianingsih Syam, N., \& Kurnia Widi Hastuti, S. (2018). Relationship Between Knowledge and Attitude with Implementation of Patient Safety Targets in RSUD Yogyakarta. Jurnal Medicoeticolegal Dan Manajemen Rumah Sakit, 7(3), 205-211. https://doi.org/10.18196/jmmr.7374

Younes, N., El, A., Saad, A., El, A., \& Zaghloul, A. A. (2012). Knowledge and performance among nurses before and after a training programme on patient falls. 2012(December), 358364. 